\title{
Pengaruh Penyulangan Medium yang Mengandung Orange II terhadap Pertumbuhan Enterococcus faecalis ID 6017 dan Kemampuan Dekolorisasinya
}

\section{The Influence of Fed Orange II Containing Medium to the Growth of Enterococcus faecalis ID 6017 and Its Decolorization Ability}

\author{
V.I. Meitiniarti*, E. Vandiyani Sunardi, K.H. Timotius \\ Fakultas Biologi, Universitas Kristen Satya Wacana, Jl. Diponegoro 52-60 Salatiga \\ Telp. 0298-321212, ex. 305 Fax. 0298-321433 \\ E-mail:rien@uksw.edu; irene_meiti@yahoo.com*Penulis untuk korespondensi
}

\begin{abstract}
The influence of fed Orange II containing medium on the growth of Enterococcus faecalis ID 6017 and its decolorization ability was studied in this research. A fed batch growth was compared with the batch growth. Total Orange II added to the both was $120 \mathrm{mg} / \mathrm{L}$. In the fed batch, the Orange II was given into three steps. The first addition was at the initial culture medium. The second and third were added after the almost total decolorization or clearance of the Orange II given in the first or the second addition respectively. The culture was incubated under static condition and room temperature. The fed batch growth was better than the batch growth, seen from both aspects; their growth parameters and the decolorization ability. The biomass yield and specific growth rates of the fed batch was higher than the batch growth. Under fed batch growth, the decolorization was $85-94 \%$, while the batch growth was only $54 \%$. For achieving these performances, the fed batch growth was needed to consume more glucose.
\end{abstract}

Key words: fed Orange II, growth rate, decolorization rate, Enterococcus faecalis ID 6017

Diterima : 21 Juni 2005, disetujui : 4 Oktober 2005

\section{Pendahuluan}

Pewarna azo merupakan kelompok pewarna sintetik yang paling banyak digunakan di industri saat ini (Leisinger dan Brunner, 1986). Dilaporkan lebih dari 3000 jenis pewarna azo digunakan untuk memenuhi kebutuhan warna dalam industri makanan, tekstil, dan aplikasi printing (Coughlin et al, 2002). Orange II atau Acid Orange 7 merupakan salah satu jenis pewarna azo yang termasuk monoazo (Salle, 1961) dengan rumus kimia 1-(4'-sulfophenylazo)-2-naphtol (Kulla et al, 1983) dan biasa digunakan untuk mewarnai wool, nilon, sutera, kertas, kulit, dan sebagai indikator (Sharamik Chemical, 2003).

Buangan industri yang mengandung pewarna azo dapat menimbulkan pencemaran dan mengancam kesehatan masyarakat di lingkungan pembuangan limbah tersebut, karena beberapa pewarna azo tertentu ataupun metabolit hasil degradasinya (yaitu senyawa amina aromatik) bersifat recalcitrant, beracun, dan berpotensi sebagai karsinogen (Donlon et al., 1997). Namun beberapa jenis mikroorganisme, seperti Pseudomonas luteola (Hu, 2001; Chang et al., 2001; Chen, 2002), Sphingomonas sp. (Kudlich et al., 1996; Keck et al., 1997; Coughlin et al., 1997; Russ et al., 2000), Bacillus subtilis (Zissi dan Lyberatos, 1996), dapat mendegradasi pewarna azo.

Enterococcus faecalis ID6017, yang diisolasi dari limbah tekstil PT. Daya Manunggal Tekstil (Damatex) Salatiga, juga mampu melakukan dekolorisasi pewarna azo (Handayani et al,. 2003). Bakteri ini 
sebelumnya diidentifikasi sebagai Pseudomonas sp. SWCU 96-I01 (Liem, 1997; Meitiniarti dan Timotius, 2002). Identifikasi lebih lanjut di Universiteit Gent, Belgia, isolat ini diidentifikasi sebagai Enterococcus faecalis ID6017 (Meitiniarti dan Timotius, 2002). Pada beberapa penelitian diketahui Enterococcus faecalis ID6017 mampu mendekolorisasi Reactive Red 2 (Meitiniarti et al., 2004), Reactive Yellow 2 (Yulianawati, 2004) dan Orange II (Meitiniarti et al., 2005).

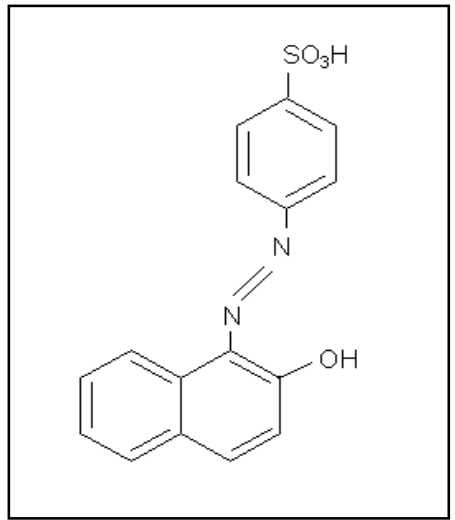

Gambar 1. Struktur Orange II (Zimmermann, et al., 1982)

Konsentrasi pewarna pada medium sangat berpengaruh terhadap pertumbuhan dan kemampuan bakteri dalam melakukan dekolorisasi. Semakin rendah konsentrasi pewarna dalam medium, semakin cepat dekolorisasi terjadi, demikian pula sebaliknya (Pearce, et al, 2003). Penelitian-penelitian sebelumnya konsentrasi awal Orange II yang diberikan untuk percobaan dekolorisasi adalah $80 \mathrm{mg} / \mathrm{L}$. Kenyataannya, pembuangan limbah yang mengandung pewarna terjadi secara terus menerus. Masuknya pewarna secara bertahap dan terjadinya degradasi tidak sempurna dari pewarna azo akan menyebabkan akumulasi senyawa antara hasil dekolorisasi dalam lingkungan. Semakin tinggi akumulasi senyawa antara akan menyebabkan pertumbuhan bakteri terhambat dan mengakibatkan kematian. Namun dapat pula terjadi proses adaptasi bakteri terhadap senyawa antara yang terbentuk.

Oleh karena itu, pada penelitian ini telah dilakukan pengamatan dan analisis pertumbuhan dan kemampuan dekolorisasi Enterococcus faecalis ID6017, yang medium pertumbuhannya dilakukan penambahan Orange II secara bertahap sampai mencapai konsentrasi $120 \mathrm{mg} / \mathrm{L}$. Diharapkan dengan penelitian ini dapat mengetahui pengaruh penyulangan medium yang mengandung
Orange II terhadap pertumbuhan Enterococcus faecalis ID6017 dan kemampuan dekolorisasinya.

\section{Metode Penelitian}

\section{Bahan}

6017 Kultur murni $\begin{gathered}\text { Enterococcus faecalis ID } \\ \text { diperoleh dari Laboratorium }\end{gathered}$ Bakteriiologi, Fakultas Biologi, Universitas Kristen Satya Wacana, Salatiga. Medium pemeliharaan menggunakan Nutrien Aagar, sedangkan untuk medium pertumbuhan menggunakan medium semisintetik dengan komposisi dasar sebagai berikut (g/L): $\mathrm{MgSO}_{4} .7 \mathrm{H}_{2} \mathrm{O} \quad 0,25 ;\left(\mathrm{NH}_{4}\right)_{2} \mathrm{SO}_{4} 1,98 ; \mathrm{K}_{2} \mathrm{HPO}_{4}$ 5,55; $\mathrm{KH}_{2} \mathrm{PO}_{4}$ 2,13; Glukosa 0,45 dan Ekstrak Khamir 0,5. Pewarna Orange II atau Acid Orange 7 (Sigma).

\section{Kondisi Pertumbuhan}

Sebanyak dua ose biakan murni Enterococcus faecalis yang berusia dua hari diinokulasikan ke dalam $110 \mathrm{ml}$ medium semisintetik tanpa pewarna dan digunakan sebagai prekultur. Prekultur kemudian diinkubasikan selama 24 - 48 jam atau sampai kerapatan optis sel pada panjang gelombang $500 \mathrm{~nm}\left(\mathrm{~A}_{500}\right)$ mencapai 0,2 - 0,3. 
Sebanyak $50 \mathrm{ml}$ prekultur diinokulasikan ke dalam botol pertumbuhan yang berisi 450 $\mathrm{ml}$ medium semisintetik yang mengandung 40 $\mathrm{mg} /$ L Orange II. Selanjutnya diinkubasi secara statis pada suhu ruang. Penyulangan medium dilakukan setelah sebagian besar Orange II dalam medium terdekolorisasi (ditandai dengan terbentuknya warna putih susu dalam medium pertumbuhan). Penyulangan dilakukan 2 kali dengan medium yang mengandung Orange II hingga konsentrasi Orange II dalam medium menjadi $40 \mathrm{mg} / \mathrm{L}$. Sebagai kontrol (tanpa penyulangan), sebanyak $50 \mathrm{ml}$ prekultur juga diinokulasikan ke dalam botol pertumbuhan yang berisi $450 \mathrm{ml}$ medium semisintetik yang mengandung $120 \mathrm{mg} / \mathrm{L}$ Orange II.

\section{Pencuplikan dan Analisis Sampel}

Pencuplikan sampel sebanyak $5 \mathrm{ml}$ dilakukan tiap selang waktu 1 jam, menggunakan jarum suntik dan dimulai segera setelah prekultur dicampurkan ke dalam medium pertumbuhan sampai pertumbuhan mencapai fase stasioner.

Sampel hasil pencuplikan dianalisis konsentrasi Orange II sisa, biomassa sel dan glukosa sisa. Analisis konsentrasi Orange II sisa dilakukan secara spektrofotometrik pada panjang gelombang 482nm. Konsentrasi biomassa sel diamati secara tidak langsung berdasarkan kekeruhan sel pada panjang gelombang 500nm yang kemudian dikonversikan ke berat kering sel. Konsentrasi glukosa sisa dianalisis dengan metode kolorimetri (metode DNSa). Data yang diperoleh dari analisis sampel digunakan untuk menghitung kecepatan pertumbuhan spesifik $(\mu)$, biomassa yang dibentuk dari $1 \mathrm{mmol}$ glukosa $\left(\mathrm{Y}_{\mathrm{glu}}\right)$, produksi biomassa, konsumsi glukosa, dekolorisasi yang terjadi dari $1 \mathrm{mmol}$ glukosa ( $\left.\mathrm{Y}_{\text {dekolorisasi }}\right)$ Orange II yang terdekolorisasi, kecepatan dekolorisasi, dan efektivitas dekolorisasi.

\section{Hasil dan Pembahasan}

Penelitian yang dilakukan menunjukkan bahwa Enterococcus faecalis ID 6017 mampu melakukan pertumbuhan dan dekolorisasi dalam medium semisintetik yang mengandung $120 \mathrm{mg} / \mathrm{L}$ Orange II. Namun penyulangan medium yang mengandung Orange II mempengaruhi pertumbuhan dan kemampuan dekolorisasi Orange II oleh Enterococcus faecalis.

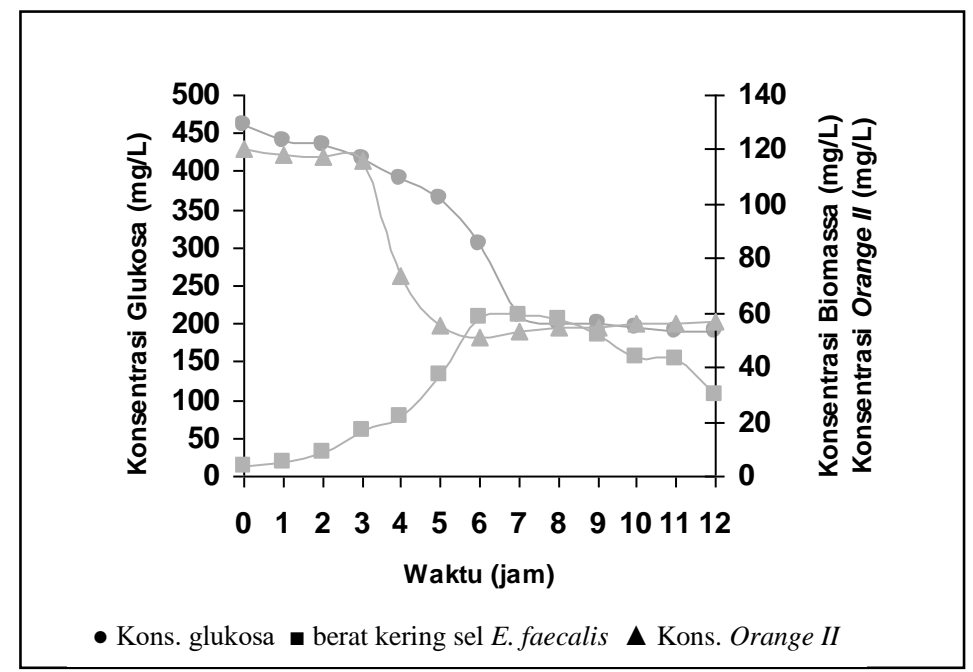

Gambar 2. Pola pemanfaatan glukosa (•) untuk pertumbuhan Enterococcus faecalis ID 6017 (๘) dan dekolorisasi pewarna Orange II ( $\mathbf{\Delta})$ dalam medium tanpa penyulangan.

Hasil penelitian menunjukkan bahwa pola penurunan konsentrasi glukosa dan
Orange II seiring dengan peningkatan berat kering sel dalam medium pertumbuhan 
(Gambar 2 dan 3). Hal ini menunjukkan bahwa Enterococcus faecalis memanfaatkan glukosa untuk pertumbuhan, sekaligus dekolorisasi Orange II. Russ, et al. (2000) mengemukakan bahwa selain untuk pertumbuhan, glukosa juga digunakan sebagai sumber donor elektron yang memacu aktivitas enzimatis (azoreduktase) untuk memutus ikatan kromofor pada Orange II, yaitu dengan memanfaatkan hasil katabolisme glukosa berupa NADH .

Pada medium pertumbuhan tanpa penyulangan diketahui bahwa dekolorisasi Orange II terjadi dalam waktu enam jam, namun Orange II yang ditambahkan ke dalam medium pertumbuhan tidak dapat sepenuhnya didekolorisasi oleh bakteri karena pertumbuhan bakteri hanya sampai jam ke-7 dan selanjutnya mengalami penurunan. Hal ini mungkin disebabkan oleh terhambatnya konsumsi glukosa akibat pembentukan senyawa hasil degradasi Orange II, yaitu asam sulfanilat dan amino naftol (Zimmermann, et al.,1982). Penghambatan konsumsi glukosa terjadi pada jam ke-7, dimana pada waktu tersebut sebagian besar Orange II dalam medium sudah mengalami dekolorisasi. Terhambatnya konsumsi glukosa ini mempengaruhi pertumbuhan dan kemampuan dekolorisasi bakteri. Semakin sedikit glukosa yang dikonsumsi bakteri, semakin sedikit energi yang diperoleh untuk pertumbuhan, pertahanan diri, dan dekolorisasi. Akibatnya pertumbuhan dan kemampuan dekolorisasi bakteri mengalami penurunan.

Bakteri dalam medium dengan penyulangan terbukti lebih mampu melakukan adaptasi dengan lingkungan hidupnya. Hal ini ditunjukkan dengan terus meningkatnya produksi biomassa sampai jam ke-16 (Gambar 3). Penyulangan medium yang mengandung Orange II ini meningkatkan kemampuan dekolorisasi bakteri (dilihat dari konsentrasi Orange II akhir). Bila dibandingkan dengan medium tanpa penyulangan, bakteri dalam medium pertumbuhan dengan penyulangan mengkonsumsi glukosa jauh lebih banyak. Waktu yang dibutuhkan untuk melakukan dekolorisasi pun jauh lebih panjang. Penyulangan medium berarti, bakteri selalu mendapatkan suplai karbon (C) dan energi yang dapat dimanfaatkan untuk melakukan pertumbuhan, pertahanan diri, dan dekolorisasi

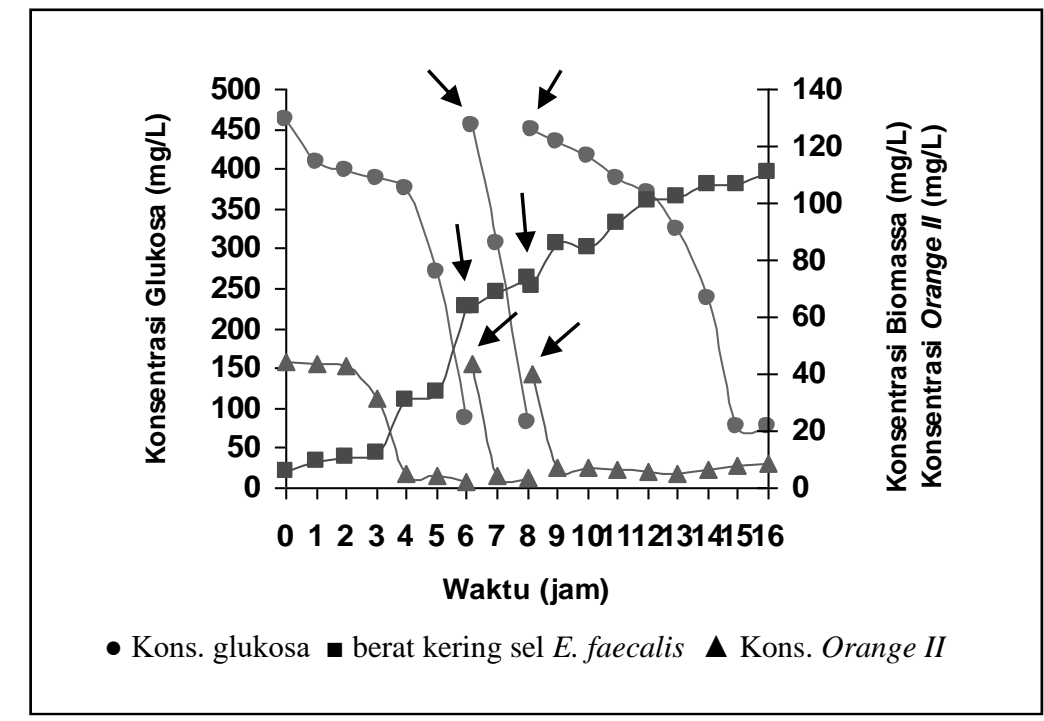

Gambar 3. Pola pemanfaatan glukosa $(\bullet)$ untuk pertumbuhan Enterococcus faecalis ID 6017 (ロ) dan dekolorisasi pewarna Orange II (ム) dalam medium dengan penyulangan.

Kecepatan pertumbuhan spesifik $(\mu)$ bakteri dalam medium pertumbuhan tanpa penyulangan $0,06 \mathrm{mg} / \mathrm{L} / \mathrm{jam}$ lebih lambat dibandingkan kecepatan pertumbuhan spesifik bakteri dalam medium pertumbuhan dengan penyulangan (Tabel 1). Hal ini mungkin disebabkan perbedaan konsentrasi Orange II pada medium. Dalam medium pertumbuhan tanpa penyulangan, konsentrasi Orange II adalah $120 \mathrm{mg} / \mathrm{L}$, sedangkan pada medium 
pertumbuhan dengan penyulangan hanya 40 $\mathrm{mg} / \mathrm{L}$. Keberadaan Orange II dalam medium bersifat ekstrim bagi pertumbuhan bakteri. Dengan demikian, semakin tinggi konsentrasi Orange II dalam medium, semakin sulit bakteri melakukan pertumbuhan.

Kecepatan pertumbuhan spesifik $(\mu)$ bakteri pada medium dengan penyulangan, setelah dilakukan penyulangan mengalami penurunan (Tabel 1). Hal ini mungkin disebabkan semakin tingginya konsentrasi metabolit antara hasil dekolorisasi dalam medium, sehingga bakteri lebih banyak memanfaatkan energi yang diperolehnya untuk melakukan pertahanan diri daripada untuk pertumbuhan atau produksi biomassa.

Tabel 1. Kecepatan pertumbuhan spesifik E. faecalis, hasil proses, dan dekolorisasi Orange II

\begin{tabular}{lcccc}
\hline \hline \multirow{2}{*}{ Parameter } & Medium tanpa & \multicolumn{2}{c}{ Medium dengan penyulangan } \\
\cline { 3 - 5 } & penyulangan & Sebelum penyulangan & Sulang pertama & Sulang kedua \\
\hline \hline$\mu(\mathrm{mg} / \mathrm{L} / \mathrm{jam})$ & 0,398 & 0,464 & 0,081 & 0,094 \\
Y $_{\text {glu }}(\mathrm{mg} / \mathrm{mmol})$ & 40,98 & 29,78 & 4,90 & 70,47 \\
Produksi biomassa $(\mathrm{mg})$ & 50,4 & 53,0 & 10,1 & 30,3 \\
Konsumsi glukosa (mM) & 1,23 & 1,78 & 2,06 & 0,43 \\
Y $_{\text {dekolorisasi }(\mathrm{mg} / \mathrm{mmol})}$ & 52,11 & 22,61 & 19,46 & 80,23 \\
Orange II yang terdekolorisasi (mg) & 64,09 & 40,24 & 40,08 & 34,50 \\
Kecepatan dekolorisasi (mg/L/jam) & 12,82 & 10,06 & 20,04 & 8,63 \\
Efektivitas dekolorisasi (\%) & 54,68 & 94,16 & 92,13 & 85,92 \\
\hline \hline
\end{tabular}

Dilihat dari nilai $\mathrm{Y}_{\text {glu }}$ dan $\mathrm{Y}_{\text {dekolorisasi }}$ (Tabel 1), diketahui bahwa bakteri dalam medium pertumbuhan tanpa penyulangan lebih efisien dalam memanfaatkan glukosa yang tersedia untuk pertumbuhan dan dekolorisasi, dibandingkan bakteri dalam medium dengan penyulangan, pada fase sebelum dan setelah penyulangan pertama. Namun demikian, lebih tingginya nilai $\mathrm{Y}$ dekolorisasi pada medium pertumbuhan tanpa penyulangan ini menunjukkan bahwa bakteri dalam medium lebih banyak memanfaatkan glukosa untuk melakukan dekolorisasi daripada pertumbuhan.

Nilai $Y_{\text {glu }}$ setelah penyulangan pertama menampakkan penurunan yang sangat drastis, yaitu sebesar 24,88 mg/mmol (Tabel 1). Biomassa yang terbentuk setelah penyulangan pertama jauh lebih rendah daripada sebelum dilakukannya penyulangan, padahal konsumsi glukosanya lebih besar. Hal ini menunjukkan bahwa bakteri pada fase ini memanfaatkan glukosa untuk kepentingan lain selain untuk produksi biomassa. Diduga bakteri memanfaatkan glukosa untuk mempertahankan diri dalam lingkungan yang mulai toksik akibat pembentukan senyawa antara hasil degradasi Orange II sebelumnya. Handayani et al, 2002 menyatakan bahwa semakin tinggi konsentrasi senyawa antara (amina aromatis) yang terbentuk dalam medium akan menghambat pertumbuhan.
Nilai $Y_{\text {glu }}$ setelah penyulangan kedua menunjukkan nilai yang paling tinggi dibandingkan yang lain, yaitu sebesar 70,47 $\mathrm{mg} / \mathrm{mmol}$ (Tabel 1). Dilihat dari nilai konsumsi glukosanya, bakteri dalam medium setelah penyulangan kedua memang mengkonsumsi glukosa paling sedikit. Hal ini menimbulkan dugaan bahwa bakteri pada fase ini tidak hanya memperoleh energi untuk melakukan pertumbuhan dari glukosa, melainkan juga dari senyawa hasil degradasi Orange II sebelumnya.

Nilai $Y_{\text {dekolorisasi pada fase setelah }}$ penyulangan kedua juga menunjukkan nilai yang paling tinggi jika dibandingkan dengan fase-fase sebelumnya dan medium pertumbuhan tanpa penyulangan (Tabel 1). Namun, lebih tingginya nilai $Y_{\text {dekolorisasi }}$ menunjukkan bahwa bakteri dalam medium pertumbuhan ini lebih banyak memanfaatkan glukosa yang tersedia untuk melakukan dekolorisasi daripada pertumbuhan.

Kecepatan dekolorisasi Orange II pada medium pertumbuhan tanpa penyulangan lebih tinggi jika dibandingkan medium dengan penyulangan (Tabel 1). Hal ini mungkin disebabkan tingginya konsentrasi Orange II yang ditambahkan dalam medium pertumbuhan (120 mg/L). Semakin tinggi konsentrasi Orange II yang ditambahkan ke dalam medium pertumbuhan akan membuat bakteri semakin 
sulit untuk melakukan degradasi, apalagi dengan waktu adaptasi yang tidak berlangsung lama. Walaupun akhirnya bakteri dapat mendegradasi senyawa tersebut, namun kecepatannya menjadi lebih lambat.

Pada dasarnya kecepatan dekolorisasi Orange II pada medium pertumbuhan dengan penyulangan tidak berbeda jauh, bahkan cenderung sama (Gambar 4). Namun demikian pada Tabel 1 dapat dilihat bahwa nilai kecepatan dekolorisasi pada tiap fasenya menunjukkan perbedaan yang signifikan. Perbedaan ini tidak disebabkan oleh penyulangan yang dilakukan, melainkan perbedaan waktu pengukuran.

Nilai efektivitas dekolorisasi bakteri dalam medium tanpa penyulangan hanya mencapai 54,68\% (Tabel 1). Hal ini mungkin disebabkan pada medium tanpa penyulangan, bakteri harus beradaptasi dengan Orange II konsentrasi tinggi $(120 \mathrm{mg} / \mathrm{L})$, selain itu juga karena lingkungan tempat hidup bakteri tersebut lebih ekstrim dan toksik.

Efektivitas dekolorisasi pada medium dengan penyulangan terlihat menurun setelah penyulangan (Tabel 1). Hal ini mungkin disebabkan oleh menurunnya kemampuan dekolorisasi bakteri karena semakin tingginya konsentrasi Orange II yang ditambahkan ke dalam medium melalui penyulangan. Faktor lain yang mungkin menyebabkan turunnya efektivitas dekolorisasi ini adalah terjadinya pembentukan warna dari produk biodegradasi anaerobik saat kontak dengan oksigen (Kapdan dan Oztekin, 2003). Pembentukan warna baru inilah yang kemudian meningkatkan kembali intensitas warna dalam medium setelah jam ke13. Warna baru ini sudah tidak dapat lagi didegradasi oleh bakteri.

\section{Kesimpulan dan Saran}

\section{Kesimpulan}

1. Pertumbuhan pada medium dengan penyulangan lebih baik daripada medium tanpa penyulangan, dilihat dari aspek pertumbuhan dan kemampuan dekolorisasinya. Produksi biomassa dan kecepatan pertumbuhan pada medium dengan penyulangan lebih tinggi daripada medium tanpa penyulangan. Selain itu pada medium dengan penyulangan,

2. Dekolorisasi pada medium dengan penyulangan lebih besar (85-94\%) dibanding pada medium tanpa penyulangan (54\%), karena bakteri dalam medium pertumbuhan dengan penyulangan mengkonsumsi glukosa lebih banyak daripada bakteria dalam medium pertumbuhan tanpa penyulangan.

\section{Saran}

Bakteri diduga memperoleh energi tidak hanya dari glukosa (dalam hal ini senyawa hasil degradasi Orange II) karena pada medium dengan penyulangan, bakteri mengkonsumsi glukosa sedikit namun produksi biomassa tinggi (nilai $\mathrm{Y}_{\mathrm{glu}}$ besar), sehingga disarankan untuk penelitian lebih lanjut membuktikan kebenaran dugaan tersebut.

\section{Daftar Pustaka}

Chang, J-S., Chou, C., Lin, Y-C., Lin, P-J., Ho, J-Y. and $\mathrm{Hu}$, T.L. 2001. Kinetic Characteristic of Bacterial Azo-dye Decolorization by Pseudomonas luteola. Water Research 35 (12): 2841-2850.

Chen, B.Y. 2002. Understanding Decolorization Characteristics of Azo Dyes by Pseudomonas luteola: Toxicity and Kinetics. Process Biochemistry. 38 (2002): 437-446.

Coughlin, M.F., Kinkle, B.K., Tepper, A. and Bishop, P.L. 1997. Characterization of Aerobic Azodye-degrading Bacteria and Their Activity in Biofilms. Water Science and Technology 36 (1): 215-220.

Coughlin, M.F., Kinkle, B.K. and Bishop, P.L. 2002. Degradation of Acid Orange 7 in Aerobic Biofilm. Chemosphere. 46: 11-19.

Donlon, B., Razo-Flores, E., Luijten, M., Swarts, H., Lettinga, G. and Field, J. 1997. Detoxification and Partial Mineralization of the Azo Dye Mordant Yellow 1 in A Continuous Upflow Anaerobic Sludgeblanket Reactor. Applied Microbiology and Biotechnology 47: 83-90.

Handayani, W., Meitiniarti, V.I. dan Timotius, K.H. 2003. Kemampuan Penghilangan Warna Reactive Red 2 oleh Kultur Campur Enterococcus faecalis ID 6017 dan Chryseobacterium indologenes ID 6016. Seri Penelitian Fakultas Biologi. 6 (1): 472-484. 
$\mathrm{Hu}$, T.L. 2001. Kinetic of Azoreductase and Assessment of Toxicity of Metabolic Products from Azodyes by Pseudomonas luteola. Water Science and Technology 43 (2): 261-269.

Kapdan, I.K. and Oztekin, R. 2003. Decolorization of Textile Dyestuff Reactive Orange 16 in Fedbatch Reactor under Anaerobic Condition. Enzyme and Microbial Technology. 33 (2003): 231-235.

Keck, A., Klein, J., Kudlich, M., Stolz, A., Knackmuss, H-J. and Mattes, R. 1997. Reduction of Azodyes by Redox Mediators Originating in the Naphthalenesulfonic Acid Degradation Pathway of Sphingomonas sp. strain BN6. Applied and Environmental Microbiology 63 (9): 3684-3690.

Kudlich, M., Bishop, P.L., Knackmuss, H-J. and Stolz, A. 1996. Simultaneous Anaerobic and Aerobic Degradation of the Sulfonated Azo Dye Mordant Yellow 3 by Immobilized Cells from A Naphthalenesulfonated-degrading Mixed Culture. Applied Microbiology and Biotechnology 46 (5/6): 597-603.

Kulla, H.G., Klausener, F., Meyer, U., Lüdeke, B. and Leisinger, T. 1983. Interference of Aromatic Sulfo Groups in the Microbial Degradation of the Azo Dyes Orange I and Orange II. Archives of Microbiology. 135: 1-7.

Leisinger, T. dan Brunner, W. 1986. Poorly Degradable Substances. Biotechnology, A Comprehensive Treatise. Vol 8. Microbial Degradation. VCH Verlagsgesellschaft mbH, Weinheim.

Liem, J.L. 1997. Identifikasi dan Karakterisasi Isolatisolat Bakteri Pereduksi Amaranth yang Telah Diisolasi dari Limbah Industri Tekstil. Skripsi. Fakultas Biologi UKSW. Salatiga.

Meitiniarti, V.I. dan Timotius, K.H. 2002. Karakterisasi dan Identifikasi Bakteri SWCU96-I03 dan SWCU96-I01 serta Pertumbuhan dan Kemampuan Dekolorisasinya pada Medium yang Mengandung Pewarna. Laporan penelitian Fak. Biologi, UKSW, Salatiga.
Meitiniarti, V.I., Napitupulu, M.M. dan Timotius, K.H. 2004. Pertumbuhan Curah Enterococcus faecalis ID6017 dan Kemampuan Dekolorisasi Reactive Red-2 pada Medium yang Mengandung Gliserol. BIOTA vol. IX (1): $19-24$.

Meitiniarti, V.I., Soetarto, E.S., Timotius, K.H. dan Hendrawan, J.T. 2005. Dekolorisasi Pewarna Azo Orange II oleh Enterococcus faecalis ID6017 dan Chryseobacterium indologenes ID 6016. Berkala Ilmiah BIOLOGI 4 (5): 303-313.

Pearce, C.I., Lloyd, J.R. and Guthrie, J.T. 2003. The Removal of Colour from Textile Wastewater Using Whole Bacterial Cells: A Review. Dyes and Pigments. 58 (2003): 179-196.

Russ, R., Rau, J. and Stolz, A. 2000. The Function of Cytoplasmic Flavin Reductases in the Reduction of Azo Dyes by Bacteria. Applied Environmental Microbiology. 66 (4): 14291434.

Salle, A.J. 1961. Fundamental Principles of Bacteriology. Fifth Edition. McGraw-Hill Book Company. New York.

Sharamik Chemical. 2003. Acid Orange 7. http://www.chemnet.com/show/sharamik/epr oduct/00001162.html.

Yulianawati, S. 2004. Pengaruh Konsentrasi Reactive Yellow 2 dan Jumlah Inokulum terhadap Pertumbuhan serta Kemampuan Dekolorisasi Enterococcus faecalis ID 6017. Skripsi. Fakultas Biologi UKSW. Salatiga.

Zimmerman, T., Kulla, H.G. and Leisinger, T. 1982. Properties of Purified Orange II Azoreductase, the Enzyme Initiating Azo Dye Degradation by Pseudomonas KF46. Europe Journal of Biochemistry 129: $197-$ 203.

Zissi, U. and Lyberatos, G. 1996. Azo-dye Biodegradation under Anoxic Conditions. Water Science and Technology 34 (5-6): 495500. 